\title{
Lifestyle: A Comparative Study of the Arts and Science college students
}

\author{
Vikas K. Rohit ${ }^{1}$, Dr. Suresh M. Makwana ${ }^{2}$
}

\section{ABSTRACT:}

Main purpose of the research is to find out the Lifestyle among Arts and Science college students so investigator selected two groups one is Arts students and other is Science college students, both groups have 200 peoples. In one group has 100 Arts and other one groups has 100 Science college students. The all subjects were randomly selected from P.G. departments of various colleges of Anand district. Scale was use for data collection is personal datasheet and Life style scale developed by S. K. Bawa and S. Kaur, (2012), and data were analysis by ' $t$ ' test. Result show, There is no any significant difference in the Lifestyle of Types of students, Social status, Types of families and Religion.

Keywords: Lifestyle, Arts-Science students.

\section{INTRODUCTION:}

Lifestyle is a living style which not only affects the individual who adopts it but also affects the society. The term lifestyle was propounded by Alfred Adler in 1929. It defines the attitude, values and somewhat exhibits the social position. Moreover it also includes pattern of social relations, consumption, entertainment and dressing style. It reflects person's views, habits and etiquettes and the way of life which has the direct influence on the type of services that person gives or requires.

Lifestyle of youth in India is a taking a rapid turn with the fast changing world. Influence of globalization, modernizations, changing needs of the society and awareness is making the youth more and more ambitious, hence affecting their lifestyle. it can be studied through their orientation to career, society, family education and trend seeking attitude. The way one lives has a great impact on the competencies of an individual to get success and satisfaction in life. Every individual has different way and style of living. Thus, lifestyle can be defined as "a person's pattern of living expressed through his/her activities, interests and opinions."

\footnotetext{
${ }^{1} \mathrm{Ph}$. D. Research Scholar, Department of Psychology, S. P. University, V.V.Nagar, Gujarat.

${ }^{2}$ Professor, Department of Psychology, S. P. University, V.V.Nagar, Gujarat.

Editor-in Chief, IJIP
} 


\section{Lifestyle: A Comparative Study of the Arts and Science college students}

Lifestyle typically reflects an individual's attitude, values or world view therefore a Life style is a means of self and to create cultural symbols that resonates with personal identity. Not all respects of a Life style are voluntary. Surrounding social and technical system can constrain the Life style choices available to the individuals and the symbol he/she is able to project to others and the self.

A way of living of individual, families (household) and societies, which they main feast in coping with their physical, Psychological, social and economical environments on a day to day basis. Lifestyle is expressed in both work and leisure behavior patterns and (on an individual basis) in activities, attitudes, interest, opinions, values and allocation of income.

"'Lifestyle' as a set of attitudes, habits or professions associated with a particular person or group"

\section{$\rightarrow$ Collins English dictionary}

"Individuals pattern of living as reflected by interest, opinion, spending habits and activities."

\section{$\rightarrow$ Barrons marketing dictionary}

"Lifestyle generally means a pattern of individuals practice and personal behaviour choices that are related to elevated or reduced health risk.

\section{$\rightarrow$ Gale encyclopedia of public health}

Your Life style can be healthy or unhealthy based on your food, choices activities level and behaviour. A positive Life style can brings you happiness, while a negative Life style can lead to sadness, illness and depression.

The following is an incomplete list of lifestyles found in the 21 st century. This list uses a definition of lifestyle as any habits of social relations, consumption, dress, and recreation that are important enough to significantly influence the lives of a sector of the population, and hence can be used as a basis of social classification.

These are not well-defined or mutually exclusive categories; there may be considerable overlap between many of them, and an individual may identify as belonging to, or enjoying the activities associated with, more than one group. Many lifestyles can contain subclasses and subcultures. 
There are some types of lifestyle given bellow:

\section{General}
Activism
Asceticism
Modern Primitivism
Back to the land
Bohemianism
Clothes free
Communal living
Groupie lifestyle
Hippie
Nomadic
Quirky alone
Rural lifestyle

Income or profession/occupation based lifestyle

$\begin{array}{lll}\text { Criminality } & \text { Farming } & \text { Jet set } \\ \text { Piracy } & \text { Poverty } & \text { Prostitution } \\ \text { Sarariman } & \text { Workaholic } & \text { Yuppie }\end{array}$

\section{Consumption-based lifestyles}

Healthy lifestyle Digital lifestyle Conspicuous consumption

Straight edge Homelessness Voluntary simplicity

\section{Lifestyle classifications used in marketing}

$\begin{array}{lll}\text { Achievers } & \text { Affluent } & \text { Belongers (joiners) } \\ \text { Early adopters } & \text { Empty nesters } & \text { Emulators } \\ \text { Opinion leaders } & \text { Over consumers } & \text { Survivors } \\ \text { Young singles } & \text { Yuppies } & \end{array}$

\section{Military lifestyles}

$\begin{array}{lll}\text { Guerrilla / Partisan } & \text { Child soldier } & \text { Mercenary } \\ \text { Survivalism } & \text { Soldier } & \text { Terrorist }\end{array}$

\section{Sexual lifestyles}

$\begin{array}{lll}\text { BDSM } & \text { Celibacy } & \text { Chastity } \\ \text { Free love } & \text { Leather } & \text { virginity } \\ \text { Monogamy } & \text { Open marriage } & \text { Polyamory } \\ \text { Polyandry } & \text { Polygamy } & \text { Polygyny }\end{array}$

\section{Lifestyles based on spiritual or religious preferences}

$\begin{array}{lll}\text { Ahimsa } & \text { Hinduism } & \text { Bahai Faith } \\ \text { Breatharianism } & \text { Buddhism } & \text { Christianity } \\ \text { Cults } & \text { Evangelicalism } & \text { Eremitism (hermit) } \\ \text { Islam } & \text { Judaism } & \text { Missionary }\end{array}$




\section{Lifestyle: A Comparative Study of the Arts and Science college students}

\section{The Student Lifestyle Survey:}

The Student Lifestyle Survey (SLS) was carried out to explore the behaviours, perceptions and experiences of a cross-section of NUI Galway undergraduate students. The College Lifestyle and Attitudes National (CLAN) Survey was used as a guide in planning the study (Hope et al., 2005). The CLAN survey was carried out in 2002 with a sample of 3,259 full-time undergraduate students. It established a profile of student lifestyle habits in respect of general and mental health, diet, exercise, accidents and injuries, sexual health, substance use and drinking patterns. This was the first survey of health behaviours and attitudes among third level students in all Irish universities and Institutes of Technology. Coping skills, work / study balance, and alcoholrelated harm were particular areas of concern identified in the findings. The CLAN survey found that regular binge drinking was associated with a cluster of risky or harmful behaviours, such as cannabis use and cigarette smoking and other negative consequences such as money problems, academic difficulties, fights and unprotected sex (Hope et al., 2005). The definition of binge drinking used in the SLS is the same as that used in the CLAN survey, namely, consuming eight or more standard drinks on one drinking occasion. This equates to four pints of beer, a bottle of wine or seven single measures of spirits (Hope et al., 2005).

\section{AIMS OF THE STUDY:}

1. To study of the Lifestyle among Arts and Science college students.

2. To study of the Lifestyle among reserve and non-reserve categories students.

3. To study of the Lifestyle among joint and nuclear families Students.

4. To study of the Lifestyle among Hindu and Muslim Students.

\section{HYPOTHESIS:}

1. There is no significant difference between the Lifestyle of Arts and Science college students.

2. There is no significant difference between the Lifestyle of reserve and non-reserve categories students.

3. There is no significant difference between the Lifestyle of joint and nuclear families students.

4. There is no significant difference between the Lifestyle of Hindu and Muslim families students.

\section{METHOD:}

\section{Sample:}

For this research 460 Students was taken as sample from Various Arts and Science colleges of Anand districts. Out of that only 200 samples randomly selected, which are 100 Arts and 100 Science college students. All the students are selected from P.G. departments. 


\section{Lifestyle: A Comparative Study of the Arts and Science college students}

\section{Tools used:}

The following tools were used in the present study:

\section{Personal Data sheet:}

Certain personal information about respondents included in the sample of research is useful and important for research. Here also, for collecting such important information, personal data sheet was prepared. With the help of this personal data sheet, the information about Types of students, Social status, Types of family and Religion were collected.

\section{Life style scale:}

This scale is developed by S. K. Bawa and S. Kaur.(2012) This scale consists 60 items into 6 Dimension Like..

1. Health Conscious Life Style,

2. Academic Oriented Life Style,

3. Career Oriented Life Style,

4. Socially Oriented Life Style,

5. Trend Seeking Life Style,

6. Family Oriented Life Style.

It is standardized on students of Higher Education. (Adult)

\section{Scoring procedure:}

Lifestyle scale contains 60 items. Each item has five optional response, i.e., strongly Agree, Agree, Indifferent, Disagree and Strongly Disagree. The respondent has to select one option out of the given five responses: there are 43 positive item and 17 Negative items. The positive item scored as 4,3,2,1,0 and negative item scored as $0,1,2,3,4$ for the responses Strongly Agree, Agree, indifferent, Disagree and Strongly Disagree.

\begin{tabular}{|l|l|l|l|l|l|l|}
\hline No & Type of item & Strongly Agree & Agree & Indifferent & Disagree & Strongly Disagree \\
\hline 1 & Positive & 4 & 3 & 2 & 1 & 0 \\
\hline 2 & Negative & 0 & 1 & 2 & 3 & 4 \\
\hline
\end{tabular}

In this test the Reliability coefficient has been found to be $\mathbf{0 . 9 6}$. The reliability index is $\mathbf{. 9 8}$ the author has reported satisfactory validity of the questionnaire. 


\section{Statistical Analysis:}

In this study ' $\mathrm{t}$ ' test was used for statistical analysis.

Result and Discussion: Table No.1 ( $N=200)$ Means, SDs and ' $t$ ' value of life style with reference to Types of students:

\begin{tabular}{|l|l|l|l|l|}
\hline Marital status & $\mathrm{N}$ & Mean & $\mathrm{SD}$ & 't' value \\
\hline Arts & 100 & 143.60 & 13.79 & \multirow{2}{*}{$0.66(\mathrm{NS})$} \\
\cline { 1 - 4 } Science & 100 & 144.89 & 14.07 & \\
\cline { 1 - 1 } & & & & \\
\hline
\end{tabular}

It is revealed in Table no. 1 that mean score of life style in students belonging to Arts and Science collages are 143.60 and 144.89 respectively. These means indicate that Science students experienced the highest level of life style (144.89) as compared to the Arts students (143.60). The result indicate this as first sight .when ' $t$ ' value was calculated to know statistical significant of mean difference, insignificant difference was observed between Arts and Science college students. ' $t$ ' value is 0.66 (Table 1) which is statistically insignificant. Hence the null hypothesis (No. 1) was accepted. Thus the results show that Types of Students has no significant effect on life style.

Table No.2 (N=200) Means, SDs and 't' value of life style with reference to Social status:

\begin{tabular}{|l|l|l|l|l|}
\hline Social status & $\mathrm{N}$ & Mean & $\mathrm{SD}$ & 't' value \\
\hline Reserve & 95 & 144.80 & 12.91 & $0.51(\mathrm{NS})$ \\
\hline Non reserve & 105 & 143.81 & 14.82 & \\
\cline { 1 - 1 } & NS= Not significant & & \\
\hline
\end{tabular}

It is revealed in Table no. 2 that mean score of life style in students belonging to reserve and non reserve social status are 144.80 and 143.81 respectively. These means indicate that students of reserve status experienced the highest level of life style (144.80) as compared to the students of non reserve social statuses (143.81).The result indicate this as first sight .when ' $t$ ' value was calculated to know statistical significant of mean difference, insignificant difference was observed between reserve and non reserve social status. ' $t$ ' value is 0.51 (Table 2) which is 


\section{Lifestyle: A Comparative Study of the Arts and Science college students}

statistically insignificant. Hence the null hypothesis (No. 2) was accepted. Thus the results show that social status has no significant effect on life style.

Table No.3 (N=200) Means, SDs and ' $t$ ' value of life style with reference to Type of family:

\begin{tabular}{|l|l|l|l|l|}
\hline Type of family & $\mathrm{N}$ & Mean & $\mathrm{SD}$ & 't' value \\
\hline Joint & 135 & 144.61 & 14.05 & $0.48(\mathrm{NS})$ \\
\cline { 1 - 3 } Nuclear & 65 & 143.60 & 13.73 & \\
\cline { 1 - 1 } & NS= Not significant & & \\
\hline
\end{tabular}

It is revealed in Table no. 3 that mean score of life style in student belonging to joint and nuclear families are 144.61 and 143.60 respectively. These means indicate that students of joint families experienced the highest level of life style (144.61) as compared to the Students of nuclear families (143.60). The result indicate this as first sight .when ' $t$ ' value was calculated to know statistical significant of mean difference, insignificant difference was observed between joint and nuclear families. ' $t$ ' value is 0.48 (Table 3 ) which is statistically insignificant. Hence the null hypothesis (No. 3) was accepted. Thus the results show that type of family has no significant effect on life style.

Table No. $4(\mathrm{~N}=200)$ Means, SDs and ' $t$ ' value of life style with reference to religion:

\begin{tabular}{|l|l|l|l|l|}
\hline Religion & $\mathrm{N}$ & Mean & SD & 't' value \\
\hline Hindu & 135 & 143.79 & 13.11 & $0.67(\mathrm{NS})$ \\
\cline { 1 - 3 } Muslim & 65 & 145.29 & 15.53 & \\
\cline { 1 - 2 } & NS= Not significant & & \\
\hline
\end{tabular}

It is revealed in Table no.4 that mean score of life style in students belonging to Hindu and Muslim religion are 143.79 and 145.29 respectively. These means indicate that students of Muslim experienced the highest level of life style (145.29) as compared to the students of Hindu (143.79).The result indicate this as first sight .when ' $t$ ' value was calculated to know statistical significant of mean difference, insignificant difference was observed between Hindu and 


\section{Lifestyle: A Comparative Study of the Arts and Science college students}

Muslim. 't' value is 0.67 (Table 4) which is statistically insignificant. Hence the null hypothesis (No. 4) was accepted. Thus the results show that religion has no significant effect on life style.

\section{CONCLUSION:}

1. There is no significant difference between the Lifestyle of Arts and Science college students.

2. There is significant difference between the Lifestyle of reserve and non reserve categories students.

3. There is no significant difference between the Lifestyle of joint and nuclear families students.

4. There is no significant difference between the Lifestyle of Hindu and Muslim students.

\section{REFERENCES:}

1. Bawa, S. K. and Kaur, S. (2012). Manual of The Lifestyle scale.

2. Hope, A., Dring, C., \& Dring, J. (2005). The College Lifestyle and Attitudinal National (CLAN) Survey. Dublin: Department of Health and Children.

3. Sudinarayan, A. (1996). A family size and academic achievement and Lifestyle of children : A study of urban high school students in Tamilnadu, family welfare, 42 (4). pp. 5-11.

4. http://psychology.wikia.com/wiki/lifestyle

5. http://service.oxfordjournals.org/cgi/tslogin?url=http\%3A\%2F\%2Fwww.oxfordjournals,c om

6. http://countrystudies.us/india/ 